author of an improvement of steam-engines, or of any other invention contributing most to the progress of steam navigation. 4. The Bordin prize, a medal of 3,000 francs value, will be awarded for a satisfactory solution of the following problem:'To find the means of destroying, or at least seriously diminishing, the annoyance and the dangrers arising from the products of combustion issuing from the chimneys of locomotive engines, stermships, and manufactories near towns.

III Astronomy.-I. The Lalande prize, a medal of 542 francs value, will be awarded to the person who shall have made the most interesting observation, or to the memoir or the work most contributing to the progress of astronomy. 2. The Damoiseau prize, a medal of 5,000 francs value, will be awarded (in 1879) for a solution of the following question :Revise the theory of the satellites of Jupiter ; discuss the observations, and deduce from them the constants they contain, and particularly that which furnishes a clirect determination of the rate of light ; finally, construct special tables for each satellite. 3. The Valz prize, the procects of a sum of 10,000 francs, will be awarded for the most interesting astronomical observation made during the year.

IV. Privsics.--The Bordin prize, a medal of 3,000 francs value, will be awarded for a solution to the following :-Various formula have been proposed to replace Ampère's law on the action of the clements of currents; discuss these various formula and the reasons which may be alleged for giving the preference to one of them. 2. Three Lacaize prizes of I0,000 francs each will be awarded (in 1879 ) to the works or memoirs which have contributed most to the progress of physiology, physics, or chemistry.

V. Chemistry.-The Jecker prize of 10,000 francs will be awarded to the researches which the Academy judges best calculated to accelerate the progress of organic chemistry.

VI. Botany.-1. The Barbier prize of 2,000 francs will be awarded to anyone who makes a valuable discovery in surgery, medicine, pharmacy, on botany, in connection with the art of healing. 2. The illumbert prize, a medal of 2,500 francz value; the subject of this prize is a study of the mode of nutrition of fungi. 3. The Desmazières prize of $r, 600$ francs will be awarcled to the best or most useful writing on the whole or part of cryptogamy published during the year. 4. The Shore prize of 200 francs will be awarded to the author of the best memoir on the cellular cryptogams of Europe, or on the habits or matomy of a European species of insect. 5. The I3ordin prize of 3,000 francs has for its subject the following :--Explain ly direct observations and by experiments the influence which the medium exercises on the structure of plant organs (roots, stem, leaves); study the variations which terrestrial plants undergo when raised in water and those which aquatic plants undergo when forced to live in air. Explain by direct experiments the special forms of several species of maritime flora.

In medicine and surgery the Bréant prize of 100,000 francs for a cure for Asiatic cholera still stands.

One or more Montyon prizes are awarded to works or disco. veries which show the means of rendering an art or occupation less insalubrious.

The competition closes on June I each year. Works sent in are not returned, and the conditions as to the use of mottoes, concealment of names, \&c., usual to such competitions are required.

\section{UNIVERSITY AND EDUCATIONAL INTELLIGENCE}

SCrENCE IN SCHOOIS. - Sir John Lubbock has given notice on an early day to move in the House of Commons that it would be desirable to modify the Code of Education by adding elementary natural science to the subjects mentioned in Article 19, c. $\mathbf{r}$.

BrEsLAU. - The number in attendance at the University during the present winter is $I, 253$, divided as follows among the faculties:- Theological, 101; legal, 432; medical, 168 ; philosophical, 552. The University possesses one of the most valuable libraries in Germany, numbering over 400,000 volumes and several thousand valuable manuscripts.

BERN AND ZURICH.-The former University is attended at present by 410 students, the latter by 318 . Each University includes in its list nineteen female students, most of whom are preparing for medical examinations.
Libraries OF German aND AUSTRIAN UNIVERSTTES. --Most of the German States place annually considerable sums at the disposal of the University libraries. Bavaria gives her universities eacli $\mathbf{r}, 000 /$. for this purpose; Saxony grants $1,200 \%$ to Ieiprig; while in P'russia the sums vary from $600 \%$. for Greifswald to $2,000 l$. for Gottingen. In Austria, although the existence of so many different languages in the empire makes special demands on the university librarics, the Government assistance has hitherto been exceedingrly limiled. We notice, however, that in a late session of the Reiclislasr a new policy has bren alopted, and that the annual grants have been raised to $\mathbf{1}, 500 \%$. for the Vienna library, $1,000 \%$. For that at Prague, and $800 l$. for those in the other universitics.

ST. Petersiung.-On January I, 1878 , the University at St. Petersburs numbered $x, 425$ students, thirty-seven more than last year. One-seventh are in the department of IIistory and Philology, three-sevenths in Natural Sciences and Mathematics, three-seventh in Law, and one-forty-seventh in Asiatic langruages. The number of professors is ninety-three. The stutents are mostly very poor, and the pecuniary help given to them by the University amounted during the year to the sum of 12,000 . besides which, a private society of former students paid the fees for eighty-one persons.

KIEFF.--The University celebrated, during the past montit, the fifty-ninth year of its existence. Although so young it is well equipped with all the necessary adjuncts of a university, and its medical faculty is regarded as the first in Russia. The number of students at present is 773 , an increase of 160 on the previoul; year. The majority are in the medical faculty. $\Delta$ s in the ot her Russian universities, the students are recruited principally from the poorer classes, 203 being freed from the payment of lecture. fees, and 123 in addition receiving stipends amounting in the total to 36,000 roubles. $\Lambda$ himh school for ladies is at last to li opened at the University.

\section{SCIENTIFIC SERLALS}

Reatle lsitituto Lomburato dis Scicnae e Lettert. Rendiconti, vol. $x$. Fasc. xix. - Reduction of chlorates to chlorides without intervention of the so-called nascent statc of hydrogen (second part), by M. Tommasi.-On the cooling of pulverulent metallic solids, by M. Cantoni.-On temperature in relation to actual energy and the state of aggregation, by M. Grassi.-Measurement of the resistance and graduation of any galvanumeter, by M. Grassi, $-\Lambda$ school experiment and means of evaporating rapidly large quantities of liquid, by $\mathrm{M}$. Brusnatelii.

Fasc. xx.-Other experiments on the evaporation of a liquid, by M. Cantoni.--Hypertrophy and hyperplasia, by M. Sangalli. - On the first and most recent appearance in Lombardy of the Beccafico of Provence.

Kosmos, November, 1877.-On the relation of Greek naturephilosophy to modern natural science, by P'rof. F. Schultze. Part I, on the Ionic physiologists and the Pythagoreans.-On a mathematical law applicable to the theory of mutation, by $\mathrm{J}$. Delbouf.--On the variations of size of coloured floral envelopes, and their effect on the natural selection of flowers, by Hermann Miiller.-A turning point in the early history of the human race, by $\mathrm{J} . \mathrm{H}$. Becker. Part $\mathrm{I}$, on the state of things preceding the turning point (before the discovery and use of fire).

December, $1877 .-\mathrm{F}$. Schultze, on the relation of Greek natural philosophy to modern natural science, part 2, discussing Heraklitus and the Eleatic school.-W. Preyer, on the nature of life.-Fritz Müller, observations on Brazilian butterfies, part 3, dealing with the evolution of the Maracuja butterflies, and the phenomena presented by their larva, pupre, and adult forms. - A. Maurer, on the origin of articulate sounds.J. H. Becker, on the separation and reunion of races.-The number also contains a review of Mr. Darwin's work on the different forms of flowers, by Hermann Mïller.

\section{SOCIETIES AND ACADEMIES LONDON}

Geological Society, February 6.-Prof. P. M. Duncan, F.R.S., president, in the chair. - James Adey Birds, Rev. George E. Comerford-Casey, M.A., Lieut.-Col. H. H. Godwin-Austen, Sir Willoughby Jones, Bart., and Henry Richard Ladell, M.A., were elected Fellows of the Society. -The following communi- 